PAWEe NowaK

Uniwersytet Pedagogiczny, Kraków

\title{
Poziom innowacyjności polskiej gospodarki na tle krajów UE
}

Pozycja innowacyjna gospodarki jest kluczowym wyznacznikiem jej perspektyw. Istnieje głęboka świadomość znaczenia rozwoju wynalazczości i innowacji w UE. Jednym z celów Strategii Lizbońskiej z 2000 r. było zwiększenie przez kraje członkowskie UE wydatków na rozwój innowacyjnej gospodarki do poziomu 3\% PKB do 2010 r. Cele Strategii w zakładanym czasie nie zostały osiągnięte, ale zostały podtrzymane w nowym planie „Europa 2020”.

Ocena stanu gospodarki odbywa się na podstawie wskaźników pośrednich i bezpośrednich. Wskaźniki pośrednie oparte są na intensywności badawczo-rozwojowej, natomiast wskaźniki bezpośrednie na rezultatach innowacji produktowych, procesowych, organizacyjnych i marketingowych. Każda z grup wskaźników obarczona jest pewnymi mankamentami. Pierwsza grupa wskaźników kładzie nacisk na innowacje technologiczne i wskazuje raczej na innowacje potencjalne aniżeli faktyczne, natomiast druga stosowana jest od niedawna i tylko w niektórych krajach. W celu uzyskania kompletnego obrazu gospodarki należy korzystać z każdej z tych dwóch grup wskaźników. Na ich podstawie można ocenić stan gospodarki i wskazać kierunki dalszych zmian.

\section{WSKAŹNIKI INNOWACYJNOŚCI GOSPODARKI}

Według GUS-u działalność innowacyjna to szereg działań o charakterze naukowym (badawczym), technicznym, organizacyjnym, finansowym i handlowym (komercyjnym), których celem jest opracowanie i wdrożenie nowych lub ulepszonych wyrobów i procesów, przy czym wyroby te i procesy są nowe przynajmniej z punktu widzenia wprowadzającego je przedsiębiorstwa (GUS 2010).

Według A.J. Schumpetera, autora Teorii rozwoju gospodarczego, uznawanej za pierwsze kompleksowe ujęcie zjawiska innowacji, innowacje to „nowe kombinacje czynników” wytrącające ze stanu równowagi gałęzie, w których te kombinacje się pojawiają. Szeroko rozumiane przez autora innowacje to kombinacje produkcyjne i handlowe, a każda zmiana, 
która modyfikuje względną rzadkość czynników produkcji lub zwiększa użyteczność towarów istniejących tworzy nową użyteczność (Schumpeter 1960, s. 102-104).

Najnowsze publikacje Eurostatu i OECD definiują innowacje w szeroki sposób jako wdrożenie nowego lub znacznie ulepszonego produktu, procesu, nowej metody marketingowej lub nowej metody organizacji w praktyce biznesowej, w miejscu pracy i w stosunkach zewnętrznych (Oslo Manual).

Mierniki pośrednie mierzą wyniki działalności wynalazczej i na ich podstawie formułowane są wnioski na temat sytuacji innowacyjnej gospodarki. Są to wskaźniki zastępcze oparte na pozytywnym związku pomiędzy poziomem nakładów na $\mathrm{B}+\mathrm{R}$ oraz produktywnością i rentownością przedsiębiorstw. Wydatki na $\mathrm{B}+\mathrm{R}$ i PKB wykazują wysoki poziom korelacji, jednak nie można $\mathrm{z}$ tego wyciągać wniosku, że zachodzi między nimi zależność przyczynowo-skutkowa - w nowoczesnej gospodarce są one mocno powiązane i to wszystko co można powiedzieć na ten temat (Godin 2004, s. 121-122). Dla krajów zaawansowanych technologicznie, należących do czołówki technologicznej można przyjąć ścisłą zależność pomiędzy wysokością wydatków na badania a tempem wzrostu gospodarczego.

Istnieją dwie główne grupy wskaźników wykorzystywanych do pomiaru innowacyjności gospodarek:

- wskaźniki pośrednie oparte na wielkości nakładów i efektów związanych z działalnością badawczą i rozwojową,

- bezpośrednie wskaźniki innowacyjności.

Pierwsza grupa mierników opiera się na wielkości nakładów na działalność badawczo-rozwojową, ilości patentów, intensywności technologicznej i statystyce patentowej. Obliczanie wydatków na badania i rozwój dotyczy sektora przedsiębiorstw, państwowego i szkolnictwa. Według GUS-u działalność badawczo-rozwojowa „to systematycznie prowadzone prace twórcze, podjęte dla zwiększenia zasobu wiedzy, w tym wiedzy o człowieku, kulturze i społeczeństwie, jak również dla znalezienia nowych zastosowań dla tej wiedzy" (GUS 2010). Jak pokazują dane Unijnej tablicy innowacyjności za 2010 r. opublikowane przez Komisję Europejską w 2011 r., nakłady na prace badawcze i rozwojowe są znacznie węższą kategorią niż wydatki na działalność innowacyjną (Unijna...). Po przyjęciu w październiku 2010 r. komunikatu „Unia innowacji” zmodyfikowano uznany i wiarygodny instrument oceny innowacyjności w państwach członkowskich UE, jakim była europejska tablica wyników innowacyjności (European Innovation Scoreboard - EIS) i przemianowano ją na „unijną tablicę innowacyjności” (Innovation Union Scoreboard - IUS). Unijną tablicę innowacyjności (IUS) opracowuje na zlecenie Dyrekcji Generalnej KE ds. Przedsiębiorstw i Przemysłu centrum ds. badań i szkoleń ekonomiczno-społecznych w zakresie innowacyjności i technologii w Maastricht (UNU-MERIT).

Największą cześć wydatków innowacyjnych w Polsce stanowią pieniądze przeznaczone na zakup maszyn i urządzeń. Firmom z krajów odrabiających dystans, takich jak Polska, bardziej opłaca się kupić ucieleśnioną technologię aniżeli prowadzić we własnym zakresie kosztowne prace badawczo-rozwojowe.

Do lat 90. XX wieku nie istniały międzynarodowe standardy bezpośredniego pomiaru innowacji. Posługiwano się miarami pośrednimi (zastępczymi), odwołującymi się do wielkości nakładów i efektów związanych z działalnością B+R. Opierając się na nakładach na działalność badawczo-rozwojową przyjmuje się założenie, że tego typu wydatki tworzą innowacyjną gospodarkę. Takie podejście potwierdza sensowność zaangażowania państwa 
w działalność badawczo-rozwojową. Ponieważ wiedza jest dobrem publicznym, państwo powinno wspierać działalność $\mathrm{B}+\mathrm{R}$, którą ze względu na charakter dobra nie jest zainteresowany w dostatecznym stopniu sektor prywatny.

Miary działalności badawczo-rozwojowej obejmują dwa rodzaje wskaźników:

- wydatki pieniężne na prace badawczo-rozwojowe,

- zatrudnienie w sektorze badawczo-rozwojowym.

W odniesieniu do gospodarki narodowej powszechnym wskaźnikiem pośrednim jest GERD (gross expenditure on research and development) - nakłady krajowe brutto na działalność $\mathrm{B}+\mathrm{R}$, które obejmują wszystkie nakłady poniesione w danym roku na działalność $\mathrm{B}+\mathrm{R}$ na terenie kraju niezależnie od źródła pochodzenia środków. Wskaźnik GERD składa się z trzech części: BERD (business expenditures on research and development) - części tworzonej przez przedsiębiorstwa; HERD (higher education on research and development) - części tworzonej przez szkolnictwo i GOVERED (government expenditures on research and development) - wydatków rządowych.

Wskaźnik GERD obliczany jest według metodologii Frascati, której zalecenia metodologiczne zawarte zostały w podręczniku OECD znanym jako Frascati Manual. Metodologia Frascati obejmuje wszelkie wytyczne dotyczące przede wszystkim metodologii badań statystycznych, klasyfikacji nakładów na działalność $\mathrm{B}+\mathrm{R}$ oraz personelu zatrudnionego w działalności $\mathrm{B}+\mathrm{R}$. Stanowi ona jednocześnie powszechnie przyjęty międzynarodowy standard metodologiczny stosowany w większości krajów rozwiniętych.

Metodologia Frascati klasyfikuje badania na podstawowe, stosowane i prace rozwojowe. Badania podstawowe nie są ukierunkowane na uzyskanie zastosowań praktycznych, badania stosowane obejmuja prace teoretyczne i eksperymentalne w celu zdobycia nowej wiedzy mającej konkretne zastosowania praktyczne, natomiast prace rozwojowe mają na celu wykorzystanie istniejącej wiedzy do wytworzenia nowych lub ulepszonych wyrobów, procesów lub usług (GUS 2010).

Kolejnym wskaźnikiem pośrednim opartym na nakładach na B+R jest wysoka technika. Określenie wysoka technika dotyczy tych dziedzin aktywności gospodarczej, w których stosunek wydatków na badania i rozwój do wartości sprzedaży jest wysoki. Na początku wskaźniki intensywności technologicznej stosowano dla przemysłu, jednak wraz ze wzrostem znaczenia sektora usług od połowy lat 90. XX wieku wskaźnik ten liczony jest także dla tego sektora.

Obecna klasyfikacja przemysłów stworzona została w 1995 r. i dzieli przedsiębiorstwa na cztery kategorie:

- wysoką technikę (high-technology industries) - powyżej 5\% udziału B+R w obrocie,

- średnio wysoką technikę (medium-high-technology industries) - 3-5\% udziału B+R,

- średnio niską technikę (medium-low-technolgy industries) - 1-3\% udziału $\mathrm{B}+\mathrm{R}$,

- niską technikę (low-technology industries) 0-1\% udziału B+R.

Do podstawowych miar opartych na intensywności technologicznej zalicza się:

- wskaźnik udziału w wartości dodanej i zatrudnieniu przemysłów i usług wysokiej i średnio-wysokiej techniki,

- wskaźniki handlu międzynarodowego wyrobami wysokiej i średnio-wysokiej techniki.

Im większy udział firm wysokiej techniki w gospodarce, tym wyższy poziom innowacyjności kraju. W największym stopniu do zwiększenia konkurencyjności gospodarki przy- 
czyniają się firmy zaliczane do wysokiej techniki. Intensywność technologiczna jest silnie powiązana z wielkością wydatków na badania i rozwój.

Innymi miernikami opartymi na aktywności badawczo-rozwojowej są wskaźniki patentowe. Patent to umowa między wynalazcą a władzami publicznymi, które udzielają wnioskodawcy ograniczonego czasowo monopolistycznego prawa użytkowania wynalazku technicznego. Wskaźniki innowacji mogą nie uwzględniać wielu innowacji o charakterze innym niż wynalazczy i technologiczny, dlatego sugerują raczej poziom wynalazczości a nie innowacji. Można je traktować jako wskaźniki potencjalnych a nie realnych innowacji rynkowych.

Jednym z głównych mierników efektów aktywności patentowej jest wskaźnik określający liczbę wynalazków zgłoszonych do opatentowania oraz liczbę uzyskanych patentów. Pod pojęciem wynalazku rozumie się pewną nowość, która nie jest częścią dotychczasowego stanu techniki. Wynalazek uważa się za posiadający poziom wynalazczy, jeżeli nie wynika on dla znawcy, w sposób oczywisty, ze stanu techniki. Na wynalazek może być udzielony patent, jeśli tylko jego wykorzystanie nie jest sprzeczne z porządkiem publicznym lub dobrymi obyczajami.

Jednocześnie do wynalazków nie zalicza się (Potencjat...):

- odkryć, teorii naukowych i metod matematycznych;

- wyrobów o charakterze jedynie estetycznym;

- planów zasad i metod dotyczących działalności umysłowej i gospodarczej oraz gier;

- wytworów, których niemożliwość wykorzystania może być wykazana w świetle powszechnie przyjętych i uznanych zasad nauki;

- oprogramowania maszyn cyfrowych;

- przedstawienia informacji.

Procedura zgłoszenia wynalazków może przebiegać zarówno w trybie krajowym jak również w trybie międzynarodowym PCT. PCT - Patent Co-operation Treaty (Układ o Współpracy Patentowej) został podpisany 19 czerwca 1970 roku w Waszyngtonie. Wszedł on w życie 1 czerwca 1978 roku, wprowadzając międzynarodowe zgłoszenia patentowe pociągające za sobą te same skutki co zgłoszenia w trybie krajowym w każdym z państw sygnatariuszy układu. Polska przystąpiła do Układu o Współpracy Patentowej w grudniu 1990 roku. Tryb krajowy dotyczy wszystkich rodzajów zgłoszeń wpływających bezpośrednio do urzędu patentowego danego kraju, pochodzących z terenu tego kraju oraz z zagranicy na mocy Konwencji Paryskiej z 1883 roku. Tryb międzynarodowy PCT dotyczy zgłoszeń patentowych dokonywanych w urzędzie patentowym danego kraju przez nierezydentów w ramach Układu o Współpracy Patentowej.

Bardzo dynamiczny wzrost liczby wniosków patentowych wskazuje na przyspieszenie postępu technologicznego w XXI wieku. Kraje azjatyckie szybko budują gospodarkę opartą na wiedzy - w ciągu 4 lat Chiny zwiększyły liczbę wniosków do WIPO (World Intellectual Property Organization) ponad trzykrotnie, a Korea Płd. o 140\%. Europę środkowo-wschodnią dzieli olbrzymia przepaść od pierwszej dziesiątki liderów światowej innowacyjności, a w Polsce nastąpił w ostatnich latach regres (Raport...).

Statystyka patentów potwierdza pozycje krajów oparte na wysokości wydatków na działalność B+R. Tylko kraje ponoszące duże wydatki są w stanie osiągać wysokie wskaźniki intensywności patentowania. Kraje posiadające dużą lukę technologiczną nie są w stanie dogonić krajów z czołówki. Przedsiębiorstwom z tych krajów nie opłaca się prowadzić własnych badań, ponieważ taniej jest kupić technologię z kraju-twórcy, który ją taniej wytwarza. 
Wskaźniki patentowe posiadają jednak szereg mankamentów:

- niedoszacowują aktywności innowacyjnej w gałęziach mniejszej szansy technologicznej,

- przeszacowują działalność innowacyjną w firmach opartych na wiedzy, które przed przystąpieniem do współpracy z innymi firmami wolą opatentować posiadane rozwiązania,

- przeszacowują działalność innowacyjną w firmach, które mają już patent, ze względu na ich tendencję do patentowania kolejnych rozwiązań,

- niedoszacowują działalność innowacyjną w małych firmach, dla których koszt postępowania patentowego jest zbyt wysoki.

Wskaźniki bezpośrednie mierzenia innowacyjności gospodarek oparte są na metodologii Oslo. Wypracowane zostały jako efekt kilkunastomiesięcznych obrad ekspertów zajmujących się zmianami technologicznymi w gospodarce. Metodologia Oslo oparta jest na modelu powiązań łańcuchowych Rosenberga i Klina z 1986 r. Pierwsze wydanie Podręcznika Oslo miało miejsce w 1992 roku. W metodologii Oslo obowiązuje podejście podmiotowe, koncentrujące się na aktywności innowacyjnej podmiotów a nie na samych innowacjach. Innowacje są następstwem interakcji i sprzężeń zwrotnych w tworzeniu wiedzy. W metodologii Oslo rozwiązania innowacyjne nie są traktowane jako ,silnik” uruchamiający proces innowacyjny, ale są jego efektem. Działalność innowacyjna wykracza poza działalność badawczo-rozwojową. Za centralny punkt analizy przyjęto tzw. „dynamo innowacyjne”, czyli złożony układ czynników kształtujących innowacje na poziomie firmy. Wiele nowych rozwiązań nie jest przełomowych i nie jest efektem wąsko rozumianych zmian technologicznych.

Podręcznik Oslo wprowadza nową typologię innowacji obejmującą cztery rodzaje innowacji, a mianowicie (The Measurement...):

- innowacje-produkty (product innovation),

- innowacje-procesy (process innovation),

- innowacje organizacyjne (organisational innovation),

- innowacje marketingowe (marketing innovation).

Metodologia Oslo została wykorzystana w badaniach innowacyjności krajów OECD oraz UE (Community Innovation Survey - CIS). Do tej pory w UE przeprowadzono badania CIS cztery razy, po raz pierwszy w latach 1992-1993. Po każdej rundzie, w oparciu o zgromadzone doświadczenia rozszerzano i udoskonalano metodologię badań. Kolejne edycje badań CIS poszerzyły zakres badań innowacji pozaproduktowo - procesowych o marketingowe i organizacyjne oraz wyszły poza przemysł i objęły przedsiębiorstwa usługowe. Badania CIS gromadzą dane na temat bezpośrednich nakładów i efektów działalności innowacyjnej. Obejmują one m.in.: efekty innowacji produktowo-procesowych, organizacyjnych i wartość nowych i ulepszonych produktów w sprzedaży. Mimo zmian, większość pytań w badaniu CIS-4 wciąż dotyczyła innowacji produktowo-procesowych.

Zaletą wskaźników bezpośrednich jest bogactwo i różnorodność informacji na temat większej ilości aspektów procesów innowacyjnych. Wskaźniki bezpośrednie w sposób bardziej kompletny opisują zjawisko innowacyjności w porównaniu ze wskaźnikami pośrednimi. Zastosowanie wskaźników w porównaniach międzynarodowych ograniczają jednak częste zmiany w metodologii ich liczenia w ramach poszczególnych rund, jak również krótki charakter szeregów czasowych. Wadą jest także to, że koncentrują się głównie na stronie wydatkowej, co powoduje, że trudno na ich podstawie ocenić wpływ tych działań na przedsiębiorstwa i gospodarkę. Możliwość zastosowania utrudnia fakt, że metodologia Oslo jest nadal w trakcie rozwoju, a zasięg geograficzny ograniczony jest do większości państw UE. 


\section{POZYCJA INNOWACYJNA KRAJÓW CZŁONKOWSKICH UE}

Pozycję innowacyjną Europy opisują dane zawarte w tablicach wyników innowacyjności za poszczególne lata. Mają one pomóc w monitorowaniu wdrażania strategii „Europa 2020". Unijna tablica innowacyjności (IUS) z 2010 r. oparta została na 25 wskaźnikach z zakresu badań naukowych oraz innowacji, które odzwierciedlają całokształt sytuacji innowacyjnej krajów. Mają one lepiej oddawać całościowy obraz systemu badań naukowych i innowacji w poszczególnych państwach niż stosowany dotychczas katalog 29 wskaźników. W tablicy wyników innowacyjności wykorzystano najnowsze dane Eurostatu i innych uznanych w skali międzynarodowej źródeł.

Unijna tablica innowacyjności z 2010 r. obejmuje wskaźniki innowacyjności w 27 państwach członkowskich Unii Europejskiej, a także w Chorwacji, Serbii, Turcji, Norwegii, Szwajcarii, byłej jugosłowiańskiej Republice Macedonii oraz Islandii. Zawiera ona także porównania między UE-27, Stanami Zjednoczonymi, Japonią oraz państwami BRIC (Brazylia, Rosja, Indie i Chiny).

Wskaźniki w Unijnej tablicy innowacyjności podzielone zostały na trzy główne kategorie:

- „czynniki dające możliwości”, tj. podstawowe elementy umożliwiające zaistnienie innowacji (zasoby ludzkie, środki finansowe oraz wsparcie, otwarte i atrakcyjne systemy badawczo-naukowe);

- „aktywność przedsiębiorstw” - ukazującą stopień innowacyjności europejskich firm (inwestycje, powiązania i przedsiębiorczość, aktywa intelektualne); oraz

- „wyniki” - ilustrujące, w jaki sposób innowacyjność przekłada się na korzyści dla gospodarki (innowatorzy, skutki ekonomiczne) (Unijna...).

W Unijnej tablicy innowacyjności państwa członkowskie podzielono na cztery grupy: liderzy innowacji, państwa doganiające liderów, umiarkowani innowatorzy oraz innowatorzy o skromnych wynikach. Liderami innowacji są państwa skandynawskie i Niemcy. Państwa doganiające liderów, które osiągnęły wyniki zbliżone do średniej UE-27, to Austria, Belgia, Cypr, Estonia, Francja, Holandia, Irlandia, Luksemburg, Słowenia i Zjednoczone Królestwo. Wyniki osiągane przez Czechy, Grecję, Hiszpanię, Maltę, Polskę, Portugalię, Słowację, Węgry i Włochy plasują się poniżej średniej dla UE-27. Są to umiarkowani innowatorzy. Wyniki osiągane przez Bułgarię, Litwę, Łotwę, Macedonię i Rumunię plasują się znacznie poniżej średniej dla UE-27. Są to innowatorzy o skromnych wynikach.

Bułgaria, Estonia, Malta, Portugalia, Rumunia i Słowenia są liderami w zakresie dynamiki wzrostu ze średnim rocznym wskaźnikiem wzrostu znacznie powyżej 5\%. Potwierdza to zasadę, że mniej innowacyjne państwa członkowskie zazwyczaj rozwijają się szybciej niż te bardziej innowacyjne. Wydaje się jednak, że proces konwergencji jest coraz powolniejszy. Podczas gdy innowatorzy umiarkowani i innowatorzy o skromnych wynikach wyraźnie osiągają wyższą dynamikę od liderów innowacji, to brak jest konwergencji pomiędzy różnymi państwami członkowskimi w ramach grup o słabszych wynikach. Konwergencja między państwami członkowskimi występuje wśród liderów innowacji, a zwłaszcza wśród państw doganiających liderów. Konwergencja między grupami wydaje się zatem być silniejsza niż konwergencja między krajami. 


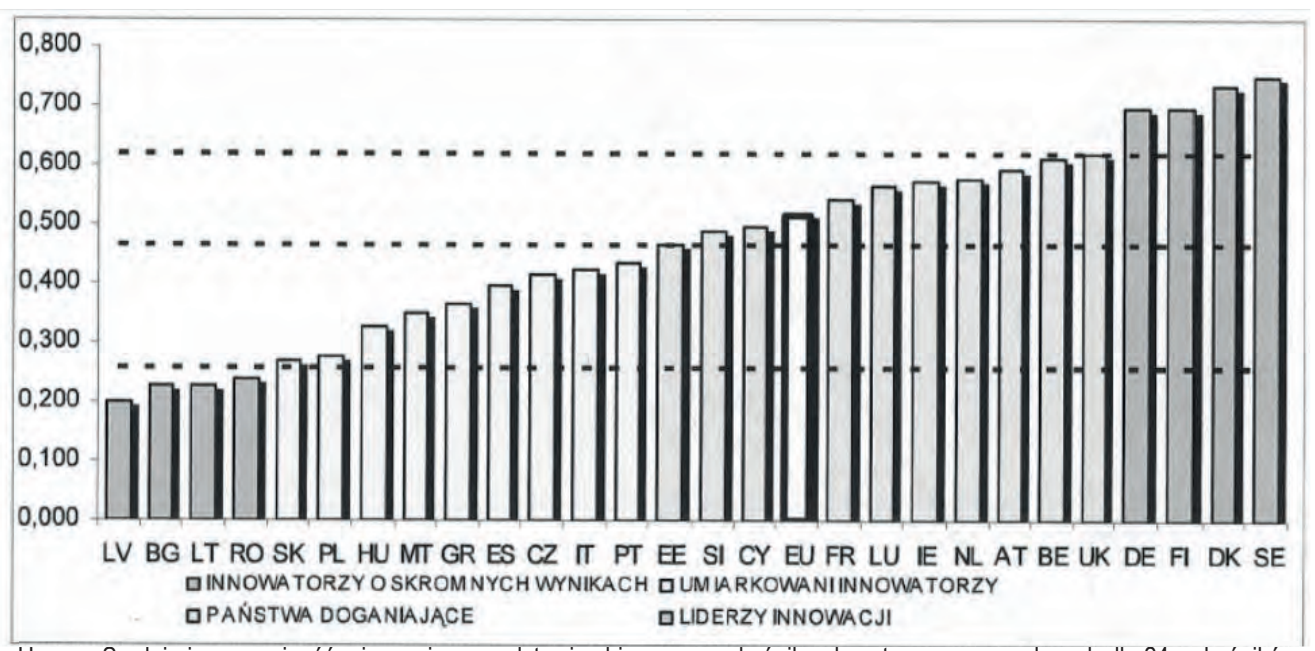

Uwaga: Srednią innowacyjność mierzy się na podstawie zbiorczego wskaźnika skonstruowanego z danych dla 24 wskaźników - od minimalnego możliwego do uzyskania wyniku (0) do wyniku maksymalnego (1). Średni wynik za rok 2010 odzwierciedla wyniki w latach 2008/2009 z powodu opóźnienia w dostępności danych. Wyniki liderów innowacji przekraczają średnią UE-27 o co najmniej 20\%; państw doganiających - są w zakresie od $10 \%$ poniżej średniej do $20 \%$ powyżej średniej; innowatorów umiarkowanych - zawierają się w przedziale od $10 \%$ poniżej średniej do $50 \%$ poniżej średniej; innowatorów o skromnych wynikach - poniżej $50 \%$ średniej dla UE-27

\section{Ryc. 1. Wyniki państw członkowskich UE w dziedzinie innowacji}

Źródło: Unijna tablica innowacyjności z 2010 r.

Choć nie istnieje jedna recepta na sukces w zakresie innowacji, większość liderów innowacji w UE osiąga przewagę w obszarze aktywności przedsiębiorstw. Najlepsi wykazują silne powiązania pomiędzy sferą biznesu i światem nauki. Istotna jest także komercjalizacja nowych technologii, przejawiająca się w dochodach uzyskiwanych z zagranicy z tytułu licencji i patentów.

Większość liderów innowacji osiąga bardzo dobre wyniki w wydatkach przedsiębiorstw na badania i rozwój oraz w przypadku innych wskaźników innowacyjności dotyczących działań przedsiębiorstw. Wszyscy liderzy innowacji mają wyniki przewyższające średnią dla wskaźnika „publiczno-prywatne wspólne publikacje naukowe na milion mieszkańców”, co wskazuje na dobre powiązania pomiędzy bazą naukową a biznesem. Wszyscy najlepsi europejscy innowatorzy wyróżniają się także komercjalizacją wiedzy technologicznej, co odzwierciedlają ich dobre wyniki dla wskaźnika „,dochody z zagranicy z licencji i patentów”.

Ponadto ogólny dobry wynik liderów innowacji wskazuje na zrównoważony krajowy system badań i innowacji. Podczas gdy każde państwo ma swoje specyficzne cechy, działania polityczne powinny odwoływać się nie tylko do relatywnie słabych stron w krajowych systemach badań i innowacji, ale także przyczyniać się do osiągania bardziej zrównoważonych wyników pomiędzy wszystkimi kategoriami wskaźników.

Wpływ kryzysu na wydatki na badania i rozwój będzie zauważalny w kolejnej tablicy wyników. Wiele zawartych w niej wskaźników opiera się na danych pochodzących z lat 2007-2008, z okresu sprzed kryzysu. Raport nie oddaje reakcji gospodarek na zachodzące zmiany. Nie ma w nim oczekiwanego spadku wydatków firm na rozwój innowacji, który za- 
deklarowało wiele z nich. W sondażu Innobarometer 2009 zmniejszenie wydatków zadeklarowały głównie firmy, które wcześniej nie wydawały dużo na innowacje. Natomiast firmy, które były liderami pod tym względem nie deklarowały zmniejszenia wydatków na ten cel. Największy spadek wydatków na innowacje będzie dotyczył krajów najbardziej dotkniętych kryzysem. Najmocniej osłabnie pozycja tych krajów, w których kryzys wywołał najgłębszą recesję. Dotyczy to zarówno krajów starej UE, takich jak Grecja i Portugalia, które należały do grupy państw najszybciej poprawiających swoją pozycję w rankingu, jak również nowych krajów członkowskich - Rumunii, Bułgarii, Litwy, Łotwy, Estonii i Węgier.

\section{POLSKA NA TLE INNYCH KRAJÓW}

W opublikowanej w 2011 r. Unijnej tablicy innowacyjności za 2010 r. Polska, podobnie jak w poprzednim roku, została zaliczona do grupy krajów doganiających. Znajduje się ona w grupie krajów, których poziom innowacyjności oscyluje poniżej średniej dla wszystkich krajów objętych badaniem, natomiast znacząco rośnie. Silne strony naszego kraju zostały powiązane z zasobami ludzkimi, inwestycjami przedsiębiorstw oraz wynikami gospodarczymi. Kwestie, które wymagają poprawy wiążą się przede wszystkim z koniecznością zwiększenia powiązań między sektorem publicznym a prywatnym, przywiązywaniem większej wagi do ochrony własności intelektualnej oraz koniecznością zwiększenia liczby innowacyjnych przedsiębiorstw. Tablica zwraca uwagę, że na przestrzeni ostatnich lat istotnie zwiększył się poziom finansowania, w tym wsparcie publiczne działalności innowacyjnej.

Nakłady wewnętrzne na badania i prace rozwojowe $(B+R)$ w Polsce wzrosły pomiędzy 2005 a 2009 r. w cenach bieżących o 62,7\%, osiągając poziom 9,07 mld zł. W odróżnieniu od okresu 2000-2005 można uznać lata 2005-2009 za okres szybszego wzrostu nakładów na B+R; w latach 2000-2005 nakłady te wzrosły jedynie o 16,2\%. Stopa wzrostu PKB w cenach bieżących wynosiła 36,6\% dla lat 2005-2009 oraz 32,1\% dla lat 2000-2004. Wzrost tzw. intensywności prac $\mathrm{B}+\mathrm{R}$, czyli udziału nakładów wewnętrznych na badania i prace rozwojowe $\mathrm{w}$ PKB, nie był już tak silny i wyniósł $17,5 \%(0,1$ pkt proc.) dla lat 2005-2009. W latach 2000-2005 obserwowano spadek intensywności prac B+R o 10,9\% (o 0,07 pkt proc.). W ciągu ostatnich dziesięciu lat Polska zwiększyła intensywność $\mathrm{B}+\mathrm{R}$ zaledwie o $0,04 \%$ do poziomu $0,67 \%$ w 2009 r. Wielkość wydatków wewnętrznych na prace badawczo-rozwojowe kształtowała się w ostatniej dekadzie na stabilnym i niskim poziomie i wynosiła w Polsce tylko 0,6\% PKB.

Według danych Eurostatu nakłady na B+R w Polsce stanowiły w 2008 r. 0,92\% nakładów odnotowanych w krajach UE-27, zaś w 2009 r. 0,89\%. W 2008 r. Polska klasyfikowana była na 22. pozycji wśród krajów Unii pod względem wskaźnika intensywności prac $B+R$, który był dla Polski ponad trzykrotnie niższy niż dla całej Unii. Z danych za 2009 r. wyni$\mathrm{ka}$, iż utrzymuje się około trzykrotnie niższa intensywność prac B+R w Polsce w stosunku do UE-27. Podobnie jak w Polsce wskaźnik ten w 2008 r. nie przekroczył 1\% w Bułgarii, na Słowacji, Litwie, Łotwie, Cyprze i Malcie. Określony dla tego wskaźnika w Strategii Lizbońskiej trzyprocentowy cel, w 2008 r. przekroczyły jedynie Finlandia i Szwecja. 
Tab. 1. Wskaźniki GERD i PKB (ceny bieżące)

\begin{tabular}{|l|c|c|c|c|c|c|}
\hline \multicolumn{1}{|c|}{ Wyszczególnienie } & 2000 & 2005 & 2006 & 2007 & 2008 & 2009 \\
\hline $\begin{array}{l}\text { Nakłady wewnętrzne } \\
\text { na badania i prace roz- } \\
\text { wojowe (GERD) } \\
\text { w mld zł }\end{array}$ & 4,80 & 5,58 & 5,89 & 6,67 & 7,71 & 9,07 \\
\hline PKB w mld zł & 744,38 & 983,30 & 1060,03 & 1176,74 & 1275,43 & 1343,66 \\
\hline $\begin{array}{l}\text { Relacja GERD } \\
\text { do PKB w \% }\end{array}$ & 0,64 & 0,57 & 0,56 & 0,57 & 0,60 & 0,67 \\
\hline $\begin{array}{l}\text { GERD } \\
\text { na 1 mieszkańca w zł }\end{array}$ & 125 & 146 & 155 & 175 & 202 & 238 \\
\hline $\begin{array}{l}\text { PKB } \\
\text { na 1 mieszkańca w zł }\end{array}$ & 19458 & 25767 & 27799 & 30873 & 33462 & 35205 \\
\hline
\end{tabular}

Źródło: Opracowanie własne na podstawie Nauka i technika w Polsce w 2009 r., GUS, Warszawa 2011, s. 81

Z ryciny 3 i 4 widać, że wyniki Polski niestety odbiegają w większości kategorii od średniej unijnej. Zarówno państwo, jak i prywatne firmy niewiele wydają na badania i rozwój. Mamy co prawda wzrost liczby osób z wyższym wykształceniem w grupie wiekowej 30-34 (o 9,6\%), ale chyba trudno uznać to za sukces, biorąc pod uwagę od dawna niełatwą sytuację absolwentów na rynku pracy. Spada liczba innowacyjnych polskich firm z sektora MŚP (o 8,3\%), coraz mniej z nich wdraża też innowacje marketingowe i organizacyjne (spadek o 7,5\%). Jako jedyne odnotowane zostały wzrost eksportu usług opartych na wiedzy (o 5,2\%), zwiększająca się liczba polskich pozycji wśród najczęściej cytowanych na świecie publikacji oraz nieznaczny wzrost zatrudnienia w sektorach gospodarki opartych na wiedzy (wzrost o 2\%).

Polska zamyka razem ze Słowacją grupę umiarkowanych innowatorów z wynikiem poniżej średniej. Należy do grupy krajów o innowacyjności wyraźnie odbiegającej od przeciętnej. Z danych Polskiej Akademii Nauk wynika, że w 2009 r. nakłady na badania i rozwój w Polsce wyniosły zaledwie 0,64\% PKB. W Hiszpanii było to 1,35\%, w Czechach 1,47\%, w Portugalii 1,51\%, na Słowacji 1,66\%, zaś we Francji 2,02\%. Średnia wydatków na naukę dla UE wynosi $1,95 \%$ PKB. Jedynie $23,9 \%$ polskich firm wprowadza innowacje, podczas gdy średnia w Unii to $40 \%$. W Niemczech $72,8 \%$ przedsiębiorstw przemysłowych jest innowacyjnych, w Irlandii 60,9\% a w Belgii 58,1\% (Innowacyjność...).

W Polsce praktycznie nie ma zachęt podatkowych dla inwestycji w innowacje. $Z$ raportu firmy Deloitte wynika, że Polska w porównaniu z głównymi krajami OECD oferuje jeden z najniższych poziomów korzyści podatkowych na jednego dolara zainwestowanego w badania i rozwój (Jak najlepiej...). Istniejące u nas ulgi podatkowe dla przedsiębiorców wprowadzających innowacje pozwalają na odliczenie tylko kosztów nabytych rozwiązań technologicznych bez uwzględnienia kosztów prac badawczo-rozwojowych prowadzonych wewnątrz firmy. W Czechach i na Węgrzech całkowita korzyść podatkowa może wynieść $200 \%$ kosztów poniesionych na prace badawcze. W Wielkiej Brytanii małe i średnie firmy mogą odliczyć nawet $175 \%$ kosztów. Firma Deloitte wyliczyła, ile centów korzyści podatkowej można uzyskać z jednego dolara zainwestowanego w badania i rozwój w poszczególnych krajach. 
W Hiszpanii było to 31 centów, w Czechach - 27, na Węgrzech - 16, a w Polsce tylko 2. Z raportu Deloitte wynika, że w latach 2006-2008 w Polsce z ulg podatkowych na badania i rozwój skorzystało jedynie 128 firm. W tym samym czasie w Wielkiej Brytanii było to 14,4 tys. podmiotów. Polscy przedsiębiorcy otrzymali zwolnienia podatkowe o łącznej wartości 27 tys. euro, a firmy brytyjskie - 1,77 mld euro. Według Deloitte jeśli Polska nie zmieni systemu ulg podatkowych, to w niedługim czasie staniemy się dla inwestorów zagranicznych mniej atrakcyjni niż Czechy, Węgry, czy inni sąsiedzi z regionu.

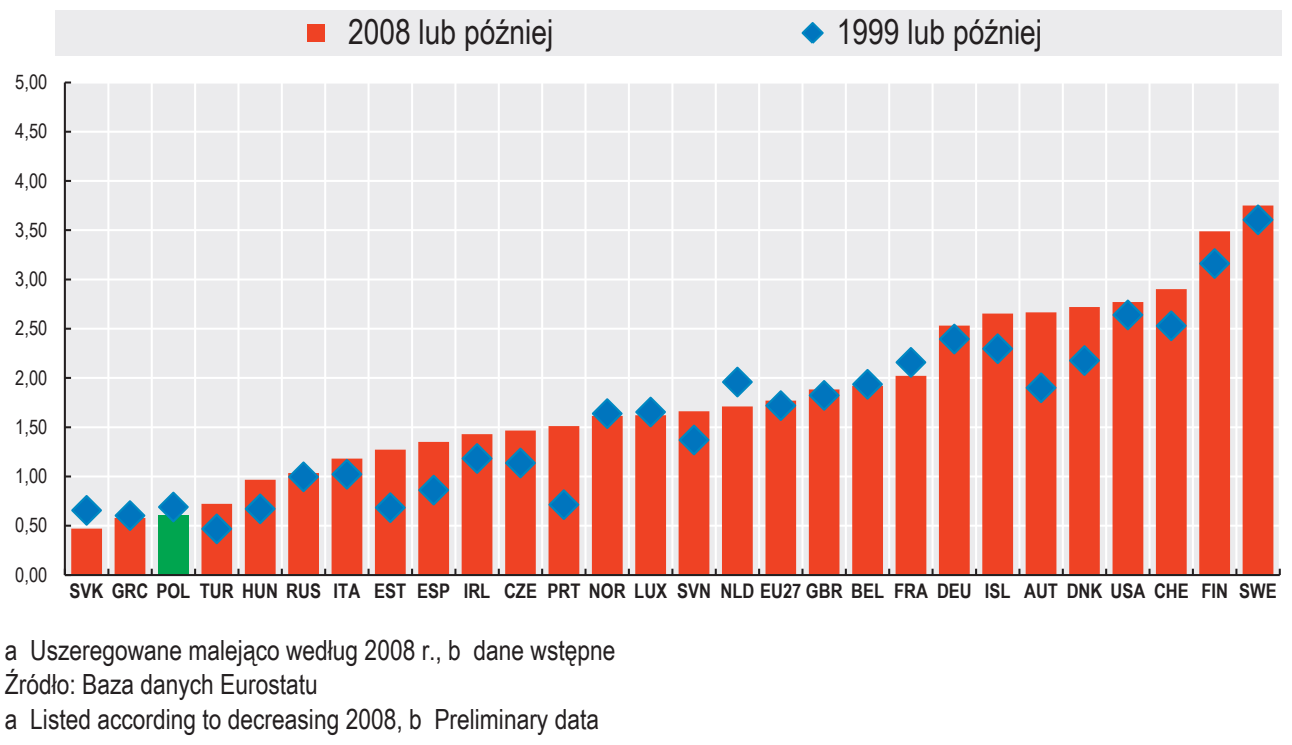

Ryc. 2. Wskaźnik intensywności prac $\mathrm{B}+\mathrm{R}$ w wybranych krajach europejskich i Stanach Zjednoczonych

Źródło: Nauka i technika w Polsce w 2009 r., GUS, Warszawa 2011, s. 82

Znaczenie ulg podatkowych dla rozwoju innowacyjności potwierdzają wyniki badań przeprowadzonych przez PKPP Lewiatan. Wyniki tych badań zostały przedstawione na rycinie 5. Uczestnicy badania wskazali za najistotniejsze ulgi podatkowe związane z wprowadzaniem nowych technologii $(52,6 \%)$ i popyt na produkty nowych technologii $(32,4 \%)$.

Największe nakłady w Polsce poniesione zostały na zakup maszyn i urządzeń, środków transportu i wyposażenia (przemysł: 62,4\%, usługi: 43,8\%), natomiast najmniejsze na szkolenia (przemysł: 0,2\%, usługi: 0,8\%). Proporcja pomiędzy środkami pozabudżetowymi i środkami z budżetu państwa wskazuje na dominację środków publicznych. Jest to proporcja odwrotna niż ta uznawana aktualnie przez ekspertów zachodnich za optymalną z punktu widzenia przydatności dla gospodarki. Zgodnie z najnowszymi ustaleniami specjalistów z Unii Europejskiej i OECD optymalny udział funduszy prywatnych i publicznych przedstawia się jak 65:35. Jeśli udział środków pochodzących spoza budżetu państwa w nakładach ogółem na działalność $\mathrm{B}+\mathrm{R}$ jest niższy niż $65 \%$, to całkowita efektywność tych nakładów jest wyraźnie mniejsza. 


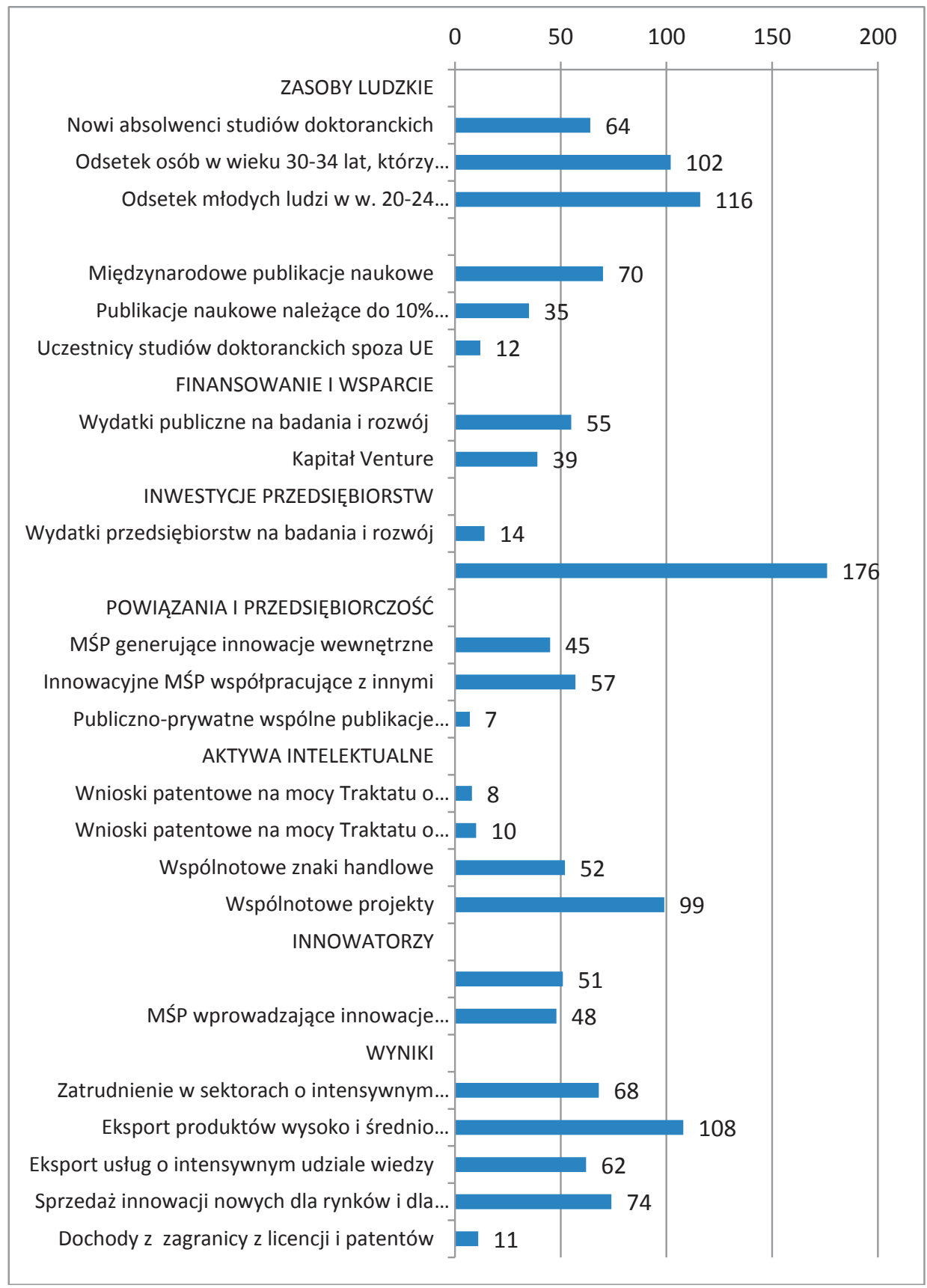

Wartości wskaźników w stosunku do UE-27 (UE-27=100)

Ryc. 3. Wartość wskaźników innowacyjności w Polsce w stosunku do średniej unijnej Źródło: Unijna tablica innowacyjności za 2010 r., s. 26 


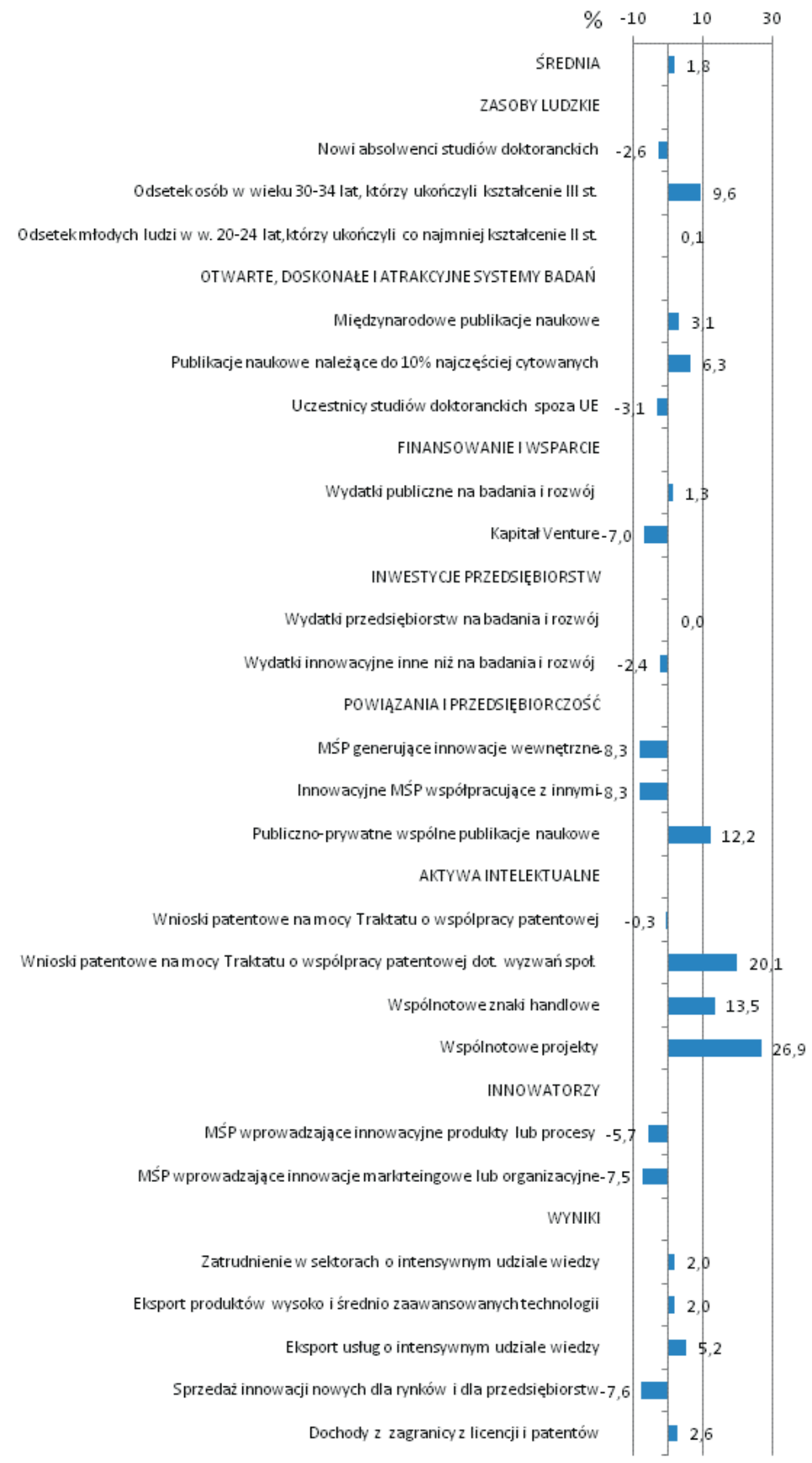

Ryc. 4. Średni roczny wzrost dla poszczególnych wskaźników i średni wzrost dla Polski Źródło: Unijna tablica innowacyjności za 2010 r., s. 26 


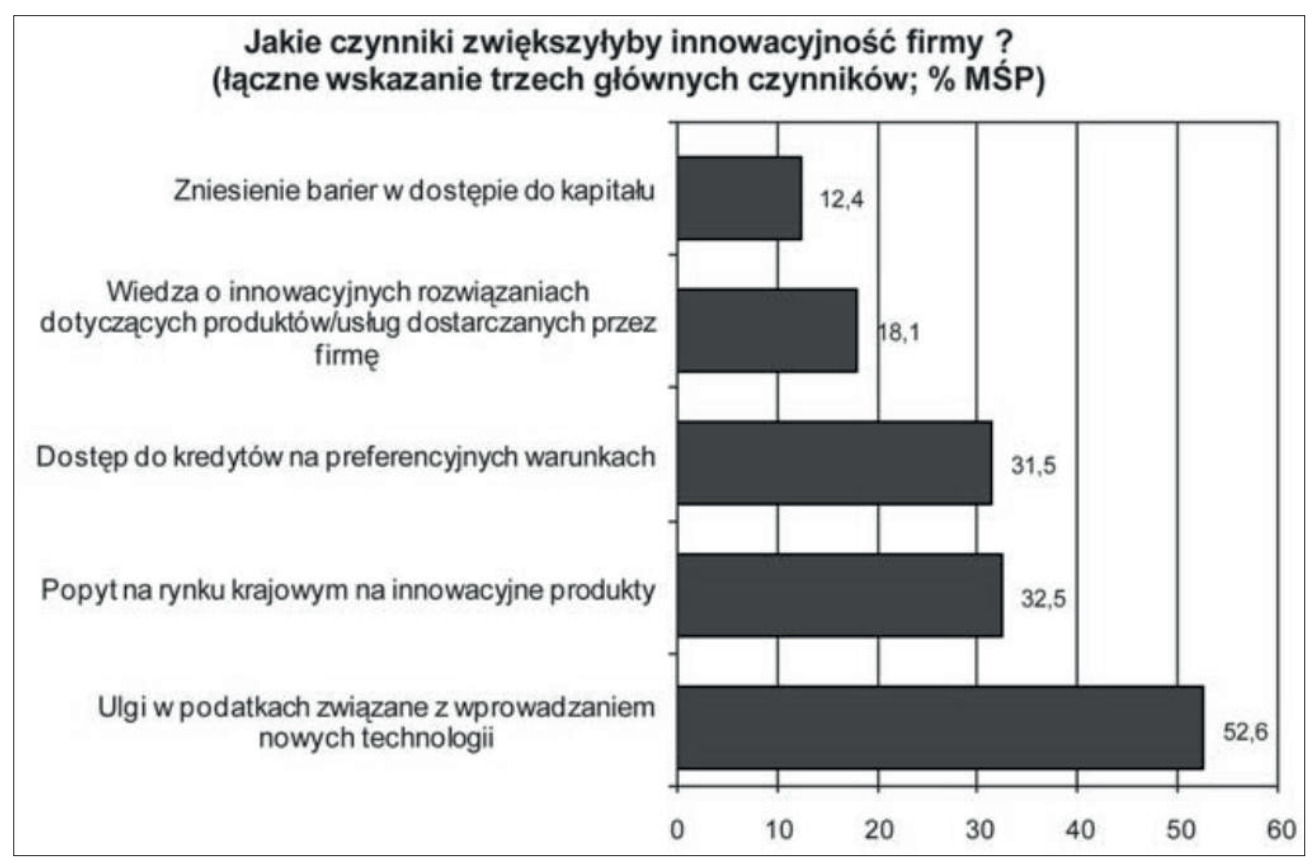

Ryc. 5. Czynniki wpływające na innowacyjność firm w opinii przedsiębiorców

Źródło: Badanie „Monitoring kondycji sektora MŚP”, PKPP Lewiatan

Słabą pozycję Polski pogarsza niższe tempo wzrostu innowacyjności aniżeli w innych krajach regionu. Większość krajów nadrabia dystans dzielący je od czołówki o wiele szybciej niż my. W ciągu ostatnich pięciu lat najszybciej odrabiającym dystans krajem w całej Unii była Rumunia. Niedaleko za nią plasowała się Bułgaria. Wśród najszybciej poprawiających swoją pozycję krajów znalazły się też Estonia, Czechy i Łotwa. Spośród państw będących na podobnym poziomie co Polska, wolniejszy rozwój był tylko na Węgrzech, a niewiele szybszy niż w Polsce - na Litwie i na Słowacji.

Relatywnie silną stroną polskiej gospodarki jest kapitał ludzki, inwestycje firm oraz efekty ekonomiczne. W tej kategorii zawarte są wskaźniki pokazujące jak działalność innowacyjna przekłada się na wzrost zatrudnienia, eksport oraz sprzedaż firm. Słabymi stronami polskiej gospodarki są z kolei „powiązania i przedsiębiorczość”. W tej kategorii mieszczą się wskaźniki pokazujące zdolność innowacyjnych firm do współpracy ze sobą, a także tworzenie więzi pomiędzy sektorem prywatnym i publicznym oraz mierzalne efekty wdrażania innowacji, takie jak liczba patentów w odniesieniu do liczby ludności, liczba zarejestrowanych wzorów użytkowych, czy wydatki na innowacje w stosunku do PKB. 
Tab. 2. Nakłady na działalność innowacyjną według rodzajów

\begin{tabular}{|c|c|c|c|c|c|c|c|}
\hline \multirow[t]{3}{*}{ Lata } & \multirow[t]{2}{*}{ Ogółem } & \multicolumn{6}{|c|}{ W tym } \\
\hline & & 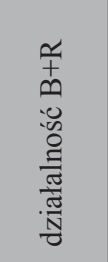 & 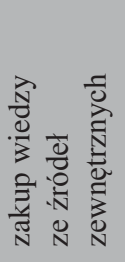 & 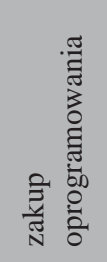 & 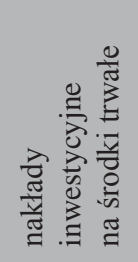 & 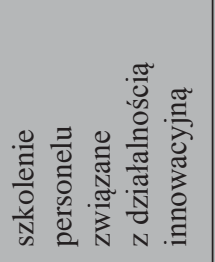 & 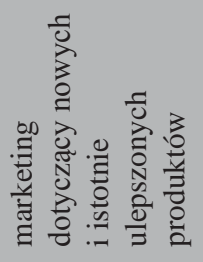 \\
\hline & \multicolumn{7}{|c|}{$\mathrm{w}$ mln zł } \\
\hline \multicolumn{8}{|c|}{ PRZEDSIĘBIORSTWA PRZEMYSŁOWE } \\
\hline 2005 & 14329,1 & 1367,1 & 343,2 & 281,9 & 11865,8 & 42,9 & 289,4 \\
\hline 2006 & 16031,0 & 1481,4 & 336,6 & 467,0 & 13058,3 & 40,3 & 462,6 \\
\hline 2007 & 19804,6 & 1602,8 & 324,2 & 340,9 & 16506,9 & 63,7 & 577,2 \\
\hline 2008 & 23686,1 & 1930,0 & 261,5 & 354,2 & 20065,7 & 201,7 & 580,1 \\
\hline 2009 & 21405,5 & 2173,1 & 267,8 & 356,6 & 17971,7 & 44,6 & 345,9 \\
\hline \multicolumn{8}{|c|}{ SEKTOR USŁUG } \\
\hline 2006 & 7214,9 & 802,4 & 292,8 & 733,9 & 4452,2 & 64,4 & 292,5 \\
\hline 2008 & 9794,6 & 556,6 & 174,2 & 1103,3 & 7329,4 & 56,1 & 266,3 \\
\hline 2009 & 7624,3 & 690,2 & 586,4 & 1162,8 & 4429,0 & 54,1 & 481,9 \\
\hline
\end{tabular}

Źródło: Opracowanie własne na podstawie Nauka i technika w Polsce w 2009 r., GUS, Warszawa 2011, s. 372

Z prognoz pochodzących z Ministerstwa Nauki i Szkolnictwa Wyższego wynika, że w 2020 r. wydatki na badania i rozwój mogą sięgnąć 1,7-1,9\% PKB. W wariancie pesymistycznym wydatki te mają wynieść około 1,45\% PKB. Ministerstwo zastrzega jednak, że określenie takiego poziomu wartości wskaźnika nakładów na badania i rozwój zostało poprzedzone przyjęciem szeregu założeń. Przyjęto m.in., że średnioroczny wzrost PKB w latach 2010-2020 wyniesie 3\%, a inflacja 1,5\%. Ponadto założono „wysoce prorozwojowy" wariant wzrostu nominalnych nakładów środków budżetowych na naukę - średniorocznie o $14 \%$. Poza tym przyjęto trzy warianty przeznaczenia środków z funduszy strukturalnych na lata 2013-2020 na badania i rozwój w kwotach 3 mld euro, 6 mld euro i 9 mld euro. Założono też dwa scenariusze udziału środków pozabudżetowych w ogólnych nakładach na badania i rozwój - 40\% (jak obecnie) i 50\%. Według resortu nauki realizacja najbardziej optymistycznego scenariusza zależy w dużej mierze od możliwości pozyskania funduszy unijnych w przyszłej perspektywie finansowej oraz zmiany dotychczasowej struktury finansowania nakładów na badania i rozwój (Za 10 lat...).

Rządowa strategia „Polska 2030” przewiduje, że nakłady na naukę wzrosną do 1,62\% PKB w 2020 r., a docelowo do 4\% w 2030 r. Aby to osiągnąć, trzeba zwiększyć wartość nakładów na badania i rozwój o $20 \%$ co roku w stosunku do poprzedniego budżetu oraz zwiększyć udział przedsiębiorstw w B+R dwukrotnie, zakładając stały wzrost PKB o 3,5\% rocznie bez uwzględnienia wartości inflacji. 


\section{WNIOSKI}

Miejsce Polski w rankingach świadczy o tym, że nasza gospodarka należy do najmniej innowacyjnych gospodarek Europy. Wzrost gospodarczy oparty jest na niskich kosztach pracy, dużym wewnętrznym rynku zbytu i funduszach z Unii Europejskiej. Zdajemy sobie jednak sprawę, że te proste rezerwy wzrostu za kilka lat się wyczerpią i Polsce będzie groził brak rozwoju.

Pod zaledwie kilkoma względami nasza pozycja innowacyjna przewyższa średnią europejską. Aktualna pozycja Polski jest wynikiem wieloletnich i wciąż utrwalanych zaniedbań. Nic nie wskazuje na to, aby Polska była w stanie nadrobić ten dystans w dającej się określić perspektywie. Deficyt sektora finansów publicznych, dług publiczny oraz nawarstwiające się problemy w strefie euro sugerują raczej dalsze cięcia i oszczędności w wydatkach na badania i rozwój. Wydatki na działalność innowacyjną w Polsce są od lat na jednym z najniższych poziomów w Europie. Współpraca sektora prywatnego i publicznego jest znikoma, a perspektywy absolwentów na rynku pracy wyglądają pesymistycznie.

Obecna sytuacja gospodarcza staje się coraz bardziej nieprzewidywalna i trudno określić perspektywy na najbliższą przyszłość. Dlatego wydaje się, że w warunkach wysokiej niepewności oraz prawdopodobnej recesji w gospodarkach krajów zachodnich, szanse na poprawę sytuacji gospodarki jako całości są małe, ale posiadają ją wciąż pojedynczy uczestnicy rynku. Dlatego rząd powinien zintensyfikować działania mające na celu zmniejszenie zbiurokratyzowania gospodarki, wprowadzić ułatwienia w zakładaniu firm oraz budować ogólnie pozytywny klimat do prowadzenia działalności gospodarczej. Polska nie musi stale zajmować dalekiego miejsca w rankingach krajów przyjaznych przedsiębiorczości. Jeżeli stanie się krajem przyjaznym inwestowaniu to ten fakt znacząco przyczyni się do poprawy obecnej pozycji Polski w zakresie innowacyjności.

\section{Literatura}

Za 10 lat wydatki na badania i rozwój sięgna 1,7 proc. PKB, http://www.wprost.pl/ar/201603/Za-10lat-wydatki-na-badania-i-rozwoj-siegna-17-proc-PKB/

Arnold E., Guy K., Technology diffusion programmes, [w:] Policy Evaluation in Innovation and Technology Best Practises, OECD.

Badanie „Monitoring kondycji sektora MŚP”, PKPP Lewiatan; http://www.pzppf.com.pl/images/pigulka/40_pl.pdf

Godin B., 2004, Obsession for Competivness and its Impact on Statistics: the Constraction of High Technology Indicators, Research Policy, nr 33.

GUS, 2010, http://www.stat.gov.pl

Innowacyjność terapia dla polskiej gospodarki, http://www.pzppf.com.pl/images/pigulka/40_pl.pdf

Jak najlepiej zachęcić do innowacyjności - ulgi podatkowe - raport 2011, http://www.deloitte.com/ view/pl_PL/pl/zagadnienia/dotacje/ulgibadaniarozwoj

Oslo Manual, 2005, OECD.

Potencjat Innowacyjny, http://www.stat.gov.pl/cps/rde/xbcr/lodz/ASSETS_potencjal_innowacyjny. pdf

Raport o kapitale intelektualnym, http://www.pliki.innowacyjnosc.gpw.pl/Kapital_Intelektualny_ Polski.pdf 
Kline S.J., Rosenberg N., 1986, An overview of innovation, [w:] R. Landau, N. Rosenberg (red.), The Positive Sun Strategy: Harnessing Technology for Economic Growth, National Academy Press, Washington D.C., s. 275-305.

Schumpeter A.J., 1960, Teoria rozwoju gospodarczego, PWN, Warszawa.

The Measurement of Specific and Technological Activities Oslo Manual Guidelines for Collecting and Interpreting Data, 3rd edition, OECD/EUROSTAT 2005, s. 95-96.

Unijna tablica innowacyjności z 2010 r., http://www.proinno-europe.eu/inno-metrics/page/innovationunion-scoreboard-2010

\section{Poland's innovative position against the background of other EU countries}

This paper presents the current innovative position of Poland against the background of other EU countries. The evaluation is based on direct and indirect indicators of the current situation of Polish economy. It provides answers to a number of questions, such as: is Poland investing enough in research? Is Poland becoming a more attractive place to invest in research? Is Poland progressing towards the European Research Area and making its research system more competitive? The figures are not optimistic. In the last ten years, $R \& D$ investment in Poland has increased only by $0,04 \%$ in real terms to $0,67 \%$ GDP in 2009. At the same time, R\&D intensity in Finland, Sweden and Denmark has increased considerably.

Dr Paweł Nowak

Uniwersytet Pedagogiczny w Krakowie

Instytut Politologii

Katedra Ekonomii i Polityki Gospodarczej

e-mail: gelb@wp.pl 